\title{
Factors Affecting Survival in Non-Small Cell Lung Cancer Patients with Brain Metastasis
}

\author{
Hakan HARPUTLUOGLU ${ }^{1}$, Nihal KAPLAN ${ }^{1}$, Mustafa DIKILITAS ${ }^{1}$, Yavuz YAGAR ${ }^{2}$ \\ Inönü University, Faculty of Medicine, Department of Medical Oncology \\ Inönü University, Faculty of Medicine, Department of Internal Medicine, Malatya, TURKEY
}

\begin{abstract}
In this study, prognostic factors in non small cell lung cancer (NSCLC) patients with brain metastasis, and relation between brain metastasis location and survival were investigated. 103 NSCLC patients with brain metastasis were enrolled in this study. Demographic, clinical characteristics and treatment modalities of the patients who were followed up in medical oncology department between May 2009 and February 2015 were assessed retrospectively using the hospital database. Brain metastasis location, treatment of brain metastasis, systemic treatment after brain metastasis and survival of the patients were recorded. The relation between these factors and survival was assessed. Follow-up period of the patients was between one and 42 months. Mean survival of the patients after brain metastasis diagnosis was 7.2 months. In the single variant analyses; patient age below 65, good performance status, detection of brain metastasis during initial diagnosis and receiving systemic treatment after brain metastasis were found to be positive prognostic factors. In the multivariant analyses; while combined treatment of brain metastasis with surgery and radiotherapy and systemic therapy after brain metastasis were found to be independent prognostic factors, no relation between location of brain metastasis and survival was found. In this study, systemic therapy including surgery, radiotherapy and chemotherapy was found as independent prognostic factors in selected patients who had NSCLC with brain metastasis. We think that defining prognostic factors in lung cancer patients with brain metastasis is important for both estimating prognosis and selecting optimal therapy for the patient.
\end{abstract}

Keywords: Lung cancer, Brain metastasis, Survival

\section{ÖZET}

\section{Beyin Metastazı Olan Küçük Hücre Dışı Akciğer Kanser Hastalarında Sağkalımı Etkileyen Faktörler}

Bu çalışmada beyin metastazı olan küçük hücre dışı akciğer kanser hastalarındaki prognostik faktörler ve beyin metastazının lokalizasyonu ile sağkalım arasındaki ilişki incelendi. Çalışmaya beyin metastazı olan 103 küçük hücre dışı akciğer kanser hastası alındı. Mayıs 2009 ile Şubat 2015 tarihleri arasında medikal onkoloji bölümünde takip edilen hastaların demografik, klinik özellikleri ve tedavi modaliteleri kullanılarak retrospektif olarak değerlendirildi. Hastaların yaş, cinsiyet, sigara içme durumu, performans statüsü, histopatolojik alt tipi, başlangıç tümör evresi, adjuvan tedavi durumu, ekstrakranial metastaz durumu, ilk metastaz yeri, beyin metastazının tanı yada takip sırasında saptanması, beyin metastaz sayısı ve lokalizasyonu, beyin metastazının tedavi şekli, beyin metastazından sonra sistemik tedavi alma durumu ve sağkalımları kayıt edildi. Hastaların sağkalımı, beyin metastaz tanısından ölüme kadar geçen süre ay olarak hesaplandı. Hastaların takip süresi 1 ile 42 ay arasındaydı. Her iki cins için median yaş 59 olarak hesaplandı. Hastaların beyin metastaz tanısından sonraki ortalama sağkalımı 7.2 ay olup 6 ve 12.aylardaki sağkalım oranları ise sırasıyla \%36 ve \%20.7 olarak bulundu. Tek değişkenli analizlerde; hastanın 65 yaşından küçük olması, iyi performans durumu, beyin metastazının tanıda saptanması, beyin metastazına cerrahi ve radyoterapi(RT) ile kombine tedavi yaklaşımı ve hastanın beyin metastazı geliştikten sonra sistemik tedavi alması sağkalımı etkileyen pozitif prognostik faktörler olarak bulundu. Çok değişkenli analizlerde ise; beyin metastazının cerrahi ve radyoterapi ile kombine tedavisi ve hastanın beyin metastazından sonra sistemik tedavi alması sağkalım için bağımsız prognostik faktörler olarak saptanırken beyin metastazının yeri ile sağkalım arasında ilişki bulunmadı. Bu çalışmada beyin metastazı olan küçük hücre-dışı akciğer kanserinde seçilmiş hasta grubunda cerrahi, radyoterapi ve kemoterapiyi içeren sistemik tedavinin sağkalım üzerinde bağımsız prognostik faktörler olduğu bulundu.

Anahtar Kelimeler: Akciğer kanseri, Beyin metastazı, Sağkalım 


\section{INTRODUCTION}

Majority of the brain malign masses in adults consist of metastatic tumors. $40-50 \%$ of these metastases are originated from lung. ${ }^{1}$ Mean survival of a patient with untreated brain metastasis is 1-3 months. ${ }^{2}$ Brain metastasis of the lung cancers have bad prognosis and they cause a traumatic experience for the patients and their families when they are symptomatic. The patient may present with headache, nausea-vomiting, diplopia, alterations in consciousness and personality as well as seizures when the brain metastasis occurs. This loss of motor and sensory function loss contributes to morbidity and mortality of the patient. Brain metastasis develops in the first two years after the patients are diagnosed with lung cancer. ${ }^{3}$ In $25-40 \%$ of non-small cell lung cancer (NSCLC) patients, brain metastasis is detected during the course of the disease. ${ }^{4}$

There is no standard therapy approach in brain metastasis of lung cancer. The management of brain metastasis can be classified as symptomatic and therapeutic approach. Symptomatic strategies include anti-edema, anti-epileptic therapies and radiotherapy (RT) whereas therapeutic strategies include surgery, stereotactic RT and systemic treatments. Whole brain radiotherapy (WBRT) is accepted as standard therapy for the patients who have more than one metastatic lesion. But survival is limited to 3-6 moths with WBRT alone. ${ }^{5}$

In the recent years, there is a shift towards more aggressive local therapy methods in selected NSCLC patients with mono or oligo brain metastases. But limited survival expectancy in patients with brain metastasis caused this group not to be considered as systemic therapy candidates. These patients were excluded in clinical studies of many systemic therapies. ${ }^{2}$

Many studies reported that select patients may benefit from combined therapy including surgery, radiotherapy and chemotherapy. ${ }^{6}$

Age, gender, pathological subtype, performance status of the patient, metastasis count, status of primary disease and extracranial metastasis status were frequently investigated as prognostic factors in lung cancer patients with brain metastasis. But effects of location of brain metastasis and systemic therapy status after metastasis on survival were investigated less frequently. In this study, we investigated the prognostic factors in lung cancer with brain metastasis and the relation between brain metastasis location and survival. Thus, we aimed to investigate which patients need more aggressive intervention and which patients need palliative follow-up.

\section{PATIENTS AND METHODS}

Demographic, clinical features and treatment modalities of 103 non-small cell lung cancer patients with brain metastasis who admitted to Medical Oncology Department between May 2009 and February 2015 were evaluated. Patient data was collected retrospectively using hospital electronic database and files. Patients between 18-90 years old who have lung carcinoma diagnosis and brain metastasis were included in the study. Pathology reports of the patients who were not diagnosed in our hospital were confirmed. Benign tumors of lung, pleural tumors and tumors without histopathological diagnosis were not included in the study. Brain metastases were confirmed using magnetic resonance imaging and computer tomography.

Survival status of the patients were estimated using hospital electronic database program of Civil Registry by Republic of Turkey identity number and survival of dead patients was estimated as the time between the day of brain metastasis detection and day of exitus. Survivals of the patients were estimated as months between brain metastasis diagnosis and death. Kaplan-Meier method was used for survival analysis whereas Log-rank test was used for subgroup comparison. Cox regression analysis was used for multivariate analysis of factors affecting survival. Significance level was accepted 0.05 in all tests.

\section{RESULTS}

Ninety one (88.3\%) of 103 patients are male whereas $12(11.7 \%)$ of them are female. Median age was 59 (35-78 years) for both genders. Follow-up periods for the patients were between 1-42 months and 100 of the patients died during follow-up whereas three of them are still alive. 
International Journal of Hematology and Oncology

Table 1. Single variant analysis of prognosis of 103 NSCLC patients with brain metastasis

\begin{tabular}{l}
\hline Age \\
$\quad<65$ \\
$\geq 65$ \\
Gender \\
Female \\
Male \\
Smoking status \\
Yes \\
No \\
Unknown \\
KPS \\
$\geq 70$ \\
$<70$ \\
Histology \\
Adenocarcinoma \\
SCC \\
Others \\
Stage \\
I-II \\
III \\
IV
\end{tabular}

Patient Number

Median Survival Time

p value

$(n=13)$

(months) $95 \% \mathrm{Cl}$

$8.3(6.3-10.3)$

0.022

$4.8(3.5-6.0)$

$10.9(6.1-15.6)$

0.146

$6.7(5.2-8.2)$

$6.8(5.2-8.5)$

0.309

$9.0(5.0-13.0)$

$2.8(1.5-4.1)$

0.004

$7.7(6.1-9.3)$

$7.7(5.6-9.8)$

0.221

$5.6(3.7-7.5)$

$10(4.2-1(5.7)$

$10.5(3.5-17.4)$

0.075

$4.5(2.3-6.5)$

$7.3(5.7-8.8)$

First Metastasis Location

Brain

$8.6(6.2-11.0)$

0.100

Bone

$3.3(1.3-5.2)$

$7.6(0.6-14.5)$

Surrenal

$9.0(0-20.4)$

Multiple

$6.1(4.2-8.1)$

Adjuvant treatment status

Yes

$6.9(3.4-10.5)$

0.782

No

$7.3(5.7-8.8)$

TKI treatment status

Yes 12

No

$6.9(5.4-8.4)$

$9.3(4.3-14.3)$

0.359

Extracranial metastasis status

Yes

$7.1(5.5-8.8)$

$7.2(4.4-10.0)$

0.996

No

Brain metastasis count

1

$2-4$

$7.1(4.8-9.5)$

$6.4(3.8-9.0)$

$7.8(5.2-10.4)$

Brain metastasis time

At diagnosis

$9.2(6.9-11.6)$

0.039

During follow-up

$6.1(4.2-7.9)$

$8.1(3.7-12.5) \quad 0.690$

$5.1(1.0-9.2) \quad 0.192$

$5.8(3.9-7.7) \quad 0.417$

$\begin{array}{ll}5.9(1.7-7.9) & 0.303\end{array}$

$\begin{array}{ll}10.8(1.8-19.7) & 0.455\end{array}$

$\begin{array}{ll}7.8(5.6-10.1) & 0.298\end{array}$

$2.0(1.3-2.6) \quad 0.0001$

$4.3(0-10.8)$

$17(12.3-21.8)$

$7(5.4-8.5)$

$13.3(10.7-16.0)$

0.0001

Systemic treatment after brain metastasis
Yes
39

$3.4(2.6-4.2)$

Abbreviations: Cl: Confidence Interval NSCLC: Non-Small Cell Lung Cancer KPS: Karnofsky Performance Status SCC: Squamouse Cell Cancer RT: Radiotherapy WBRT:Whole Brain Radiotherapy TKI: Tyrosin Kinase Inhibitor 
Table 2. Multivariant analysis of 103 NSCLC patients with brain metastasis

\begin{tabular}{|c|c|c|c|c|c|c|}
\hline & df & B & SE & Wald & $p$ value & $95 \% \mathrm{Cl}$ \\
\hline \multicolumn{7}{|c|}{ Brain metastasis treatment } \\
\hline Surgery & 1 & -1.117 & 0.645 & 3.001 & 0.083 & 0.093 \\
\hline Surgery+RT & 1 & -2.006 & 0.418 & 23.004 & 0.0001 & 0.059 \\
\hline WBRT & 1 & -1.005 & 0.271 & 13.786 & 0.0001 & 0.215 \\
\hline \multicolumn{7}{|c|}{ Systemic treatment after BM } \\
\hline Yes & 1 & -1.428 & 0.289 & 24.345 & 0.0001 & 0.136 \\
\hline
\end{tabular}

Median survivals of 103 patients were 12 months and median survival after brain metastasis was 7.2 months. Survival rate of the patients 6 and 12 months after brain metastasis was $36 \%$ and $20.7 \%$, respectively.

In the study, no statistically significant relation between gender, smoking status, initial stage of the patient, histological subtype, first metastasis location, extracranial metastasis status, brain metastasis number and location, adjuvant chemotherapy or targeted therapy during follow-up and survival was found ( $p>0.05)$ (Table 1).

Single variant analyses revealed that patient age below 65, good performance status, detection of brain metastasis at the time of diagnosis, combined therapy of brain metastasis with surgery and radiotherapy and systemic therapy after occurrence of brain metastasis as positive prognostic factors $(\mathrm{p}<$ 0.05) (Table 1).

In multivariant analyses, combined surgery and radiotherapy of brain metastasis and receiving systemic therapy after brain metastasis were found as independent prognostic factors for survival (Table 2).

Death risk of the patients whose brain metastasis was treated with RT alone decreased 2.7 times whereas that risk decreased 7.4 times with the patients whose brain metastasis treated with surgery and RT (HR: 0.135 and HR: 0.366, respectively). Risk of death decreases 4.1 times in patients who receive systemic chemotherapy after brain metastasis compared to the patients who do not receive chemotherapy (HR: 0.240).
Survival of the patients who did not receive any treatment was 2 months whereas it was 4.3 months for the patients who underwent metastasectomy, 7 months for patients who received WBRT and 17 months for the patients who had both metastasectomy and RT in the study ( $\mathrm{p}=0.0001)$ (Figure 1).

Survival in patients who receive systemic treatment for brain metastasis in NSCLC was found significantly higher compared to those who did not receive systemic treatment (3.4 moths vs 13.3 months, $\mathrm{p}=0.0001$ ) (Figure 2).

In the study, brain metastasis was detected in the multiple lobes most frequently $(44.7 \%)$ whereas solitary metastases were most frequently detected in the frontal (18.5\%) lobe and parietal lobe $(15.5 \%)$. The last frequent metastasis location was occipital lobe (3.8\%).

Systemic therapies patients received after the development of the brain metastasis, although varied in accordance with pathological and molecular characteristics of the tumor were; chemotherapy for 44 patients (paclitaxel-carboplatin, gemcitabine-cisplatin, cisplatin-etoposide, pemetrexed, docetaxel, vinorelbine, irinotecan and oral etoposide) and ten patients with EGFR mutation received erlotinib and two patient with ALK $(+)$ received crizotinib.

\section{DISCUSSION}

Brain metastasis is an important morbidity and mortality reason for lung cancer patients with brain metastasis. Although there is poor prognosis expectance in brain metastasis, reports of variable survival durations in the studies suggest that this 


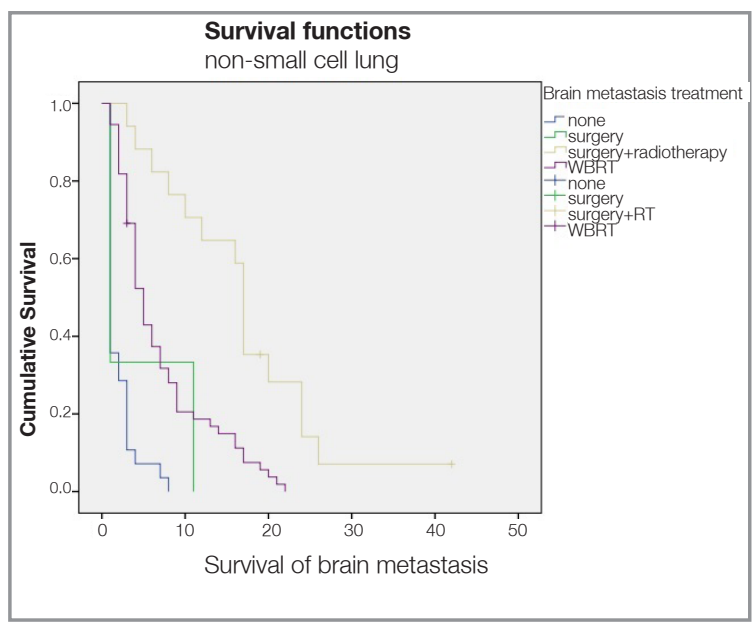

Figure 1. Survival rates of NSCLC patients with brain metastasis according to treatment modality

subgroup in the lung cancer might be heterogeneous. Survival of the patients varied with pathological, molecular, clinical and therapy characteristics of the patients in the studies. Identification of prognostic factors in these cases are important for the therapy approach. The patients who are suitable for more aggressive approach can be determined by identifying prognostic factors. Because the best survival in brain metastases can be achieved with combined therapies.

The most investigated characteristics as prognostic factors in the literature are; age, gender, histology, performance status of the patient, extracranial metastasis status, adjuvant chemotherapy status, metastasis number and affect of systemic therapy after brain metastasis to survival. ${ }^{7,89}$ But there are not many studies investigating the relation between brain metastasis location in lung cancer and survival.

In Gong et al's study, median survival in NSCLC metastasized to brain was 12.1 months, 6-month and 1-year cumulative survival rates were $80 \%$ and $50.2 \%$ respectively. ${ }^{10}$ In our study, median survival for NSCLC was 7.2 months, and 6-month and 1-year survival rates were found $36 \%$ and $20.7 \%$ respectively. The fact that survival rates in study of Gong et al are better might be related to the fact that most of the patients had adenocarcinoma histology $(70.8 \%)$ and more patient had targeted therapy $(66.8 \%)$.

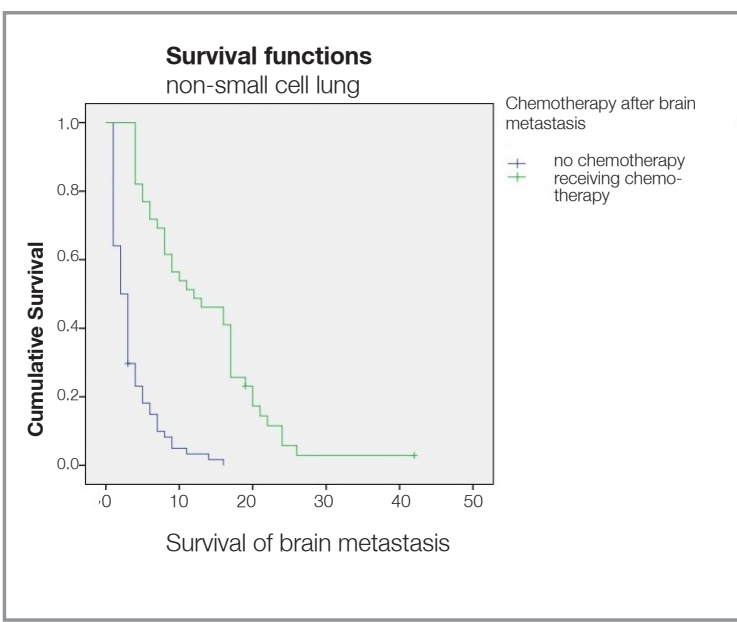

Figure 2. Survival difference of patients with brain metastatic NSCLC who received chemotherapy and did not receive chemotherapy

Similar to our study, there was a relation between performance status of the patient and survival in study of Gong et al whereas no relation between extracranial metastasis and tumor histology and survival was found in our study. Moreover in this study, survival was longer with the detection of brain metastasis one year or more after the lung cancer diagnosis but in our study, brain metastasis at the time of diagnosis was associated with better survival than brain metastasis during the followup.

In a series consisting of 1292 case by Lagerwaard et al, no relation between histopathological subtype and survival was found, and similarly no relation between histopathological subtype and survival was found in our study. ${ }^{11}$ However, three patients who are still living having adenocarcinoma histology and not having extracranial metastasis suggests that metastases of this histological subtype have a different nature and slow progression. Also, some differences in survival after systemic therapy between lung adenocarcinoma and other subtypes and better response to anti-EGFR therapy suggest need for prospective studies to determine whether histopathological subtype is a prognostic factor. ${ }^{12,13}$

Gender, histological subtype and EGFR mutation status was evaluated in study of Hideyuki et al where prognostic factors investigated with 264 patients. EGFR mutation was found as an independent prognostic factor and was associated with 
better survival. 8 In our study, no relation between these three parameters and survival was found. However, although there was 5.9 months of difference in survival between patients who received anti-EGFR treatment and those who did not, this difference was not statistically significant. Low number of patients who received anti-EGFR therapy in our study might have impacted the results.

Survival with combined therapy of brain metastasis with surgery and RT was found 17.6 months in Roberge et al's study similar to our study. ${ }^{14}$ Studies have shown addition of chemotherapy and targeted therapy to the treatment benefits the survival. ${ }^{15,16,17}$ In a study, addition of chemotherapy to the treatment was shown to increase survival of the patients with brain metastasis to 58.1 weeks. ${ }^{15}$

Most frequent brain metastasis location for different primary tumors was frontal lobe $(31.6 \%)$, second was cerebellum (24.3\%) in study of Ghia et al. ${ }^{18}$ In another study, the most frequent location was found to be cerebellum (50\%) and also cerebellum metastasis was found to have a worse prognosis. 7 In our study, the most frequent metastasis location was frontal lobe for solitary lesions. But we did not find a relation between brain metastasis location and survival. Survival might be found worse with cerebellar metastasis because the patients with cerebellar metastasis usually have low performance and are symptomatic.

Because our and other studies are retrospective and have limited number of patients, prospective studies are needed to confirm whether brain metastasis location is a prognostic factor.

In another study where prognostic factors of 135 NSCLC patients with brain metastasis were investigated, good performance status of the patient, absence of extracranial and cerebellar metastasis and receiving three cycles of combination chemotherapy and addition of anti-EGFR TKI treatment to the therapy were found positive prognostic factors. ${ }^{7}$ In our study, only good performance status and receiving systemic therapy after brain metastasis were found good as prognostic factors.

Receiving active systemic chemotherapy after brain metastasis was found positive prognostic factor in many previous studies, similar to our study. ${ }^{15}$
EGFR-TKI (erlotinib and gefitinib) being well tolerated with radiotherapy in brain metastasis and increasing survival is shown in the studies. In Welsh et al's study, response rate (RR) to erlotinib was $86 \%$ and median survival was found 11.8 months. In this study, the treatment was given regardless of the EGFR mutation status of the patients. When survival of EGFR wild and EGFR mutant patients were analyzed, it was found 9.3 months vs. 19.1 months. ${ }^{16}$ However in Tactic study, 80 NSCLC patients with brain metastasis were randomized to WBRT with erlotinib and placebo arms but, no difference was found between two groups in both neurological progression free and overall survival. But very low rate of EGFR mutation (2.9\%) might be the cause of the negative result of the study. ${ }^{19} \mathrm{In}$ the future, development of smaller and lipophilic targeted agents and molecules which can cross blood-brain barrier better might be more effective in this patient group.

In the present day, treatment modalities in lung cancer with brain metastasis are not optimal. Systemic treatments which used to be more background in this patient group are still being investigated. Although no significant benefit of any specific chemotherapeutic agent was shown, necessity of this therapy is clear considering the systemic distribution of the disease. Systemic treatment can become prominent with new medications developed for molecular subtypes of NSCLC.

In summary, prognostic factors in lung cancer patients with brain metastasis were investigated in this study. Patient age lower than 65, good performance status, detection of brain metastasis at the time of the metastasis, combined therapy of brain metastasis with surgery and RT and receiving systemic treatment after development of brain metastasis were found positive prognostic factors. No relation between brain metastasis location and survival was found. Limitations of the study may include being single-center and restrospective study.

\section{CONCLUSIONS}

Aggressive therapies should not be avoided assuming lung cancer patients with brain metastasis have limited survival. Systemic therapy should be 
considered especially with the patients who have positive prognostic factors, taking tumor characteristics into account, and the patients should be encouraged to take part in clinical studies.

\section{REFERENCES}

1. Schouten L, Rutten J, Huveneers H, Twijnstra A. Incidence of brain metastases in a cohort of patients with carcinoma of the breast, colon, kidney, and lung and melanoma. Cancer 94: 2698-2705, 2002.

2. Ali A, Goffin JR, Arnold A, Ellis PM. Survival of patients with non-small-cell lung cancer after a diagnosis of brain metastases. Curr Oncol 20: 300-306, 2013.

3. Castrucci W, Knisely J. An update on the treatment of CNS metastases in small cell lung cancer. Cancer J 14: 138-146, 2008.

4. Sørense J, Hansen H, Hansen M, Dombernowsky P. Brain metastases in adenocarcinoma of the lung: frequency, risk groups, and prognosis. J Clin Oncol 6: 1474-1480, 1988.

5. Kepka L, Cieslak E, Bujko K, Fijuth J, Wierzchowski M. Results of the whole-brain radiotherapy for patients with brain metastases from lung cancer: the RTOG RPA intra-classes analysis. Acta Oncol 44: 389-398, 2005.

6. Harita S, Mizuta A, Kuyama S, Kikuchi T. Long-term survival following concurrent chemoradiotherapy in patients with nonsmall cell lung cancer with concomitant brain metastases only. Int J Clin Oncol 10: 63-68, 2005.

7. Xiang Z, Chen J, Zhang $\mathrm{H}$, et al. Whole Brain RadiotherapyBased Combined Modality Treatment of Brain Metastases from Non-Small Cell Lung Cancer: A Retrospective Analysis of Prognostic Factors. Oncol Res Treat 38: 35-40, 2015.

8. Harada $\mathrm{H}$, Asakura $\mathrm{H}$, Ogawa $\mathrm{H}$, et al. Prognostic factors in patients with brain metastasis from non-small cell lung cancer treated with whole-brain radiotherapy. J Canc Res Ther 12: 267-270, 2016.

9. Kanou T, Okami J, Tokunaga T, et al. Prognostic factors in patients with postoperative brain recurrence from completely resected non-small cell lung cancer. Thoracic Cancer 6: 3842, 2015.

10. Gong X, Zhou D, Liang S, Zhou C. Analyses of prognostic factors in cases of non-small cell lung cancer with multiple brain metastases. OncoTargets Ther 9: 977-983, 2016.

11. Lagerwaard FJ, Lavendag PC, Nowak PJ, et al. Identification of prognostic factors in patients with brain metastases: A review of 1292 patients. Int J Radiat Oncol 43: 795-803, 1999.

12. Paz-Ares L, Soulières D, Melezinek I, et al. Clinical outcomes in non-small-cell lung cancer patients with EGFR mutations: Pooled analysis. J Cell Mol Med 14: 51-69, 2010.
13. Rosell R, Moran T, Queralt C, et al. Screening for epidermal growth factor receptor mutations in lung cancer. New Engl $\mathrm{J}$ Med 361: 958-967, 2009.

14. Roberge D, Petrecca K, El Refae M, Souhami L. Whole brain radiotherapy and tumor bed radiosurgery following resection of solitary brain metastases. J Neuro-Oncol 95: 95-99, 2009

15. Kim DY, Lee KW, Yun T, et al. Efficacy of platinum-based chemotherapy after cranial radiation in patients with brain metastasis from non-small cell lung cancer. Oncol Rep 14: $207-$ 211, 2005.

16. Welsh JW, Komaki R, Amini A, et al. Phase II trial of erlotinib plus concurrent whole-brain radiation therapy for patients with brain metastases from non-small-cell lung cancer. J Clin Oncol 31: 895-902, 2013.

17. Ma S, Xu Y, Deng Q, YuX. Treatment of brain metastasis from non-small cell lung cancer with whole brain radiotherapy and gefitinib in a Chinese population. Lung Cancer 65: 198-203, 2009.

18. Ghia A, Tomé WA, Thomas $\mathrm{S}$, et al. Distribution of brain metastases in relation to the hippocampus: Implications for neurocognitive functional preservation. Int J Radiat Oncol 68: 971 $977,2007$.

19. Lee SM, Lewanski CR, Counsell N, et al. Randomized trial of erlotinib plus whole-brain radiotherapy for NSCLC patients with multiple brain metastases. J Natl Cancer Inst 16: 106107,2014

\section{Correspondence:}

Dr. Hakan HARPUTLUOGLU

Inönü Üniversitesi

Tip Fakültesi

Turgut Özal Tip Merkezi

Tibbi Onkoloji Anabilim Dali

MALATYA / TURKEY

Tel: (+90-422) 3410660 / 5005

e-mail: harputlu@hotmail.com 